\title{
KUALITAS UDARA RUANG PERAWATAN PENYAKIT MENULAR DI RUMAH SAKIT PARU SURABAYA TAHUN 2016
}

\author{
Imro'atul Mufidah, Erna Triastuti, Ernita Sari
}

\begin{abstract}
Infectious disease treatment rooms are places with a high risk of the transmission of diseases and nosocomial infections. Therefore, there is a need for good environmental quality, either in terms of air quality, and room construction condition, cleaning process and number of occupant density.

The study was a descriptive study aimed at describing the air quality of infectious disease treatment rooms in Lung Hospital Surabaya in 2016. Data were collected by means of observations, interviews, measurements and calculation of the airborne bacterial index.

Results showed that the airborne bacterial index of inpatient rooms was $1030 \mathrm{CFU} / \mathrm{m}^{3}, 828$ CFU/m $\mathrm{m}^{3}$ and $>2628 \mathrm{CFU} / \mathrm{m}_{3}$ for Dahlia Room 1, Dahlia Room 2 and Pear Room, respectively. Room temperature was $29.8^{\circ} \mathrm{C}, 30.5^{\circ} \mathrm{C}$ and $30.9^{\circ} \mathrm{C}$ for Dahlia Room 1, Dahlia Room 2 and Pear Room, respectively. Room humidity was 69\%, 65\% and 65\% for Dahlia Room 1, Dahlia Room 2 and Pear Room, respectively. Room air velocity was eligible for Dahlia Room 1 and Dahlia Room 2 at $0.49 \mathrm{~m} / \mathrm{s}$ and 20.18 $\mathrm{m} / \mathrm{s}$ respectively, but It was not so for Pear Room at $0.89 \mathrm{~m} / \mathrm{s}$. Room lighting was 62 lux, 26 lux and 81 Iux for Dahlia Room 1, Dahlia Room 2 and Pear Room, respectively. In conclusion, the airborne bacterial index, temperature, humidity and lighting in Lung Hospital Surabaya in 2016 did not meet the requirements as defined in Decree of the Minister of Health No. 1204/Menkes/SK/X/2004 on Hospital Environmental Health Requirements.

It iis recommended to improve the cleaning and maintenance process of those rooms in accordance with health procedures and to improve construction of the rooms which do not meet the requirements.
\end{abstract}

Keywords $\quad$ : Room air quality, Hospital

\section{PENDAHULUAN}

Menurut Kepmenkes RI No. 1204 tahun 2004 tentang Persyaratan Kesehatan Lingkungan Rumah Sakit, rumah sakit merupakan sarana pelayanan kesehatan, tempat berkumpulnya orang sakit maupun orang sehat, atau dapat menjadi tempat penularan penyakit serta memungkinkan terjadinya pencemaran lingkungan dan gangguan kesehatan.

Kualitas udara dalam ruangan (Indoor Air Quality) merupakan masalah yang perlu mendapatkan perhatian karena akan berpengaruh terhadap kesehatan manusia. Menurut Nasional Institute of Occupational Safety and Health (NIOSH) 1997, penyebab timbulnya masalah kualitas udara dalam ruangan pada umumnya disebabkan oleh beberapa hal, yaitu kurangnya ventilasi $(52 \%)$, adanya sumber kontaminasi di dalam udara (16\%), kontaminasi dari luar ruangan $(10 \%)$, mikroba $(5 \%)$, bahan material bangunan $(4 \%)$, dan lain $(13 \%)$. Tingkat pencemaran udara di dalam ruangan oleh mikroba dipengaruhi oleh beberapa faktor, antara lain laju ventilasi, padatnya orang, sifat, dan taraf kegiatan orang-orang yang menempati ruangan tersebut. (Lud Waluyo,2009 : 337). Jumlah pasien yang terus meningkat dan rasio jumlah pasien terhadap luas lantai ruangan yang tidak memenuhi syarat kesehatan dapat menurunkan kualitas udara ruang rawat inap. Salah satu indikator kualitas udara dalam ruang yang rendah adalah angka kuman yang tinggi.

Rumah Sakit Paru Surabaya merupakan salah satu institusi pelayanan kesehatan dalam kategori Rumah Sakit Khusus, yang memberikan pelayanan utama pada suatu bidang atau satu jenis penyakit tertentu. pada ruang rawat inap penyakit menular pernah dilakukan pemeriksaan pada tahun 2011dengan hasil tidak memenuhi syarat. Sehingga, peneliti ingin mengetahui kualitas udara ruang rawat inap secara mikrobiologis di Tahun 2016.

Penelitian ini bertujuan untuk mengetahui kualitas udara ruang pada ruang perawatan penyakit menular di RS. Paru Surabaya Tahun 2016.

\section{METODE PENELITIAN}

Penelitian ini merupakan penelitian deskriptif, yaitu penelitian yang dilakukan untuk mendeskripsikan tentang kualitas udara di ruang perawatan penyakit menular RS. Paru Surabaya Tahun 2016. (Notoatmodjo, 2012) 


\section{HASIL DAN PEMBAHASAN}

Indeks Angka Kuman Udara Ruang Rawat Inap

Tabel 1

Indeks Angka Kuman Udara Ruang Rawat Inap RS. Paru Surabaya Tahun 2016

\begin{tabular}{|c|c|c|c|c|}
\hline No. & Ruangan & $\begin{array}{l}\text { Persyaratan Angka } \\
\text { Kuman Udara } \\
\text { (CFU } / \mathrm{m}^{3} \text { udara) }\end{array}$ & $\begin{array}{c}\text { Angka Kuman } \\
\text { Udara } \\
\text { (CFU/m³ udara) }\end{array}$ & Kriteria \\
\hline 1. & Ruang Dahlia 1 & $200-500$ & 1030 & TMS \\
\hline 2. & Ruang Dahlia 2 & $200-500$ & 828 & TMS \\
\hline 3. & Ruang Pear & $200-500$ & $>2628$ & TMS \\
\hline
\end{tabular}

Sumber : data primer

Berdasarkan tabel 1, dapat diketahui bahwa hasil pengukuran angka kuman di masing-masing ruang rawat inap didapatkan hasil pada Ruang Dahlia 1 sebesar $1030 \mathrm{CFU} / \mathrm{m}^{3}$ udara, Ruang Dahlia 2 sebesar $828 \mathrm{CFU} / \mathrm{m}^{3}$ udara, dan Ruang Pear sebesar $>2628 \mathrm{CFU} / \mathrm{m}^{3}$ udara dengan kategori tidak memenuhi syarat.
Kualitas Fisik Udara Ruang Rawat Inap

a. Suhu Udara di Dalam Ruang Berdasarkan tabel 2, dapat diketahui bahwa hasil pengukuran suhu udara di RS. Paru Surabaya pada Ruang Dahlia 1 sebesar $29,8^{\circ} \mathrm{C}$, Ruang Dahlia 2 sebesar $30,5^{\circ} \mathrm{C}$, dan Ruang Pear sebesar $30,9^{\circ} \mathrm{C}$ dengan kategori tidak memenuhi syarat.

Tabel 2

Suhu Udara Ruang Rawat Inap di RS. Paru Surabaya Tahun 2016

\begin{tabular}{clccc}
\hline No. & \multicolumn{1}{c}{ Ruangan } & $\begin{array}{c}\text { Persyaratan Suhu } \\
\text { Udara }\left({ }^{\circ} \mathrm{C}\right)\end{array}$ & Suhu Udara $\left({ }^{\circ} \mathrm{C}\right)$ & Kriteria \\
\hline 1. & Ruang Dahlia 1 & $22-24$ & 29,8 & TMS \\
\hline 2. & Ruang Dahlia 2 & $22-24$ & 30,5 & TMS \\
\hline 3. & Ruang Pear & $22-24$ & 30,9 & TMS \\
\hline
\end{tabular}

b. Kelembaban Udara di Dalam Ruang Berdasarkan tabel 3, dapat diketahui bahwa hasil pengukuran kelembaban udara

di RS. Paru Surabaya pada Ruang Dahlia 1 sebesar 69\%, Ruang Dahlia 2 sebesar $65 \%$, dan Ruang Pear sebesar 65\% dengan kategori tidak memenuhi syarat.

Tabel 3

Kelembaban Udara Ruang Rawat Inap di RS. Paru Surabaya Tahun 2016

\begin{tabular}{|c|c|c|c|c|}
\hline No. & Ruangan & $\begin{array}{c}\text { Persyaratan } \\
\text { Kelembaban Udara (\%) }\end{array}$ & $\begin{array}{c}\text { Kelembaban Udara } \\
(\%)\end{array}$ & Kriteria \\
\hline 1. & Ruang Dahlia 1 & $45-60$ & 69 & TMS \\
\hline 2. & Ruang Dahlia 2 & $45-60$ & 65 & TMS \\
\hline 3. & Ruang Pear & $45-60$ & 65 & TMS \\
\hline
\end{tabular}

c. Kecepatan Aliran Udara di Dalam Ruang

Berdasarkan Tabel 4, dapat diketahui bahwa hasil pengukuran kecepatan aliran udara ruang rawat inap di RS. Paru Surabaya pada Ruang Dahlia 1 sebesar 0,49 $\mathrm{m} / \mathrm{s}$, Ruang Dahlia 2 sebesar $0,18 \mathrm{~m} / \mathrm{s}$, dan

Ruang Pear sebesar $0,89 \mathrm{~m} / \mathrm{s}$, dengan ketegori pada ruang Dahlia 1 dan Ruang Dahlia 2 tidak memenuhi syarat, sedangkan pada Ruang Pear memenuhi syarat.

Tabel 4

Kecepatan Aliran Udara Ruang Rawat Inap di RS. Paru Surabaya Tahun 2016

\begin{tabular}{ccccc}
\hline \multirow{2}{*}{ No. } & Ruangan & $\begin{array}{c}\text { Persyaratan Kecepatan } \\
\text { Aliran Udara }(\mathrm{m} / \mathrm{s})\end{array}$ & $\begin{array}{c}\text { Kecepatan Aliran Udara } \\
(\mathrm{m} / \mathrm{s})\end{array}$ & Kriteria \\
\hline 1. & Ruang Dahlia 1 & $\leq 0,5$ & 0,49 & MS \\
\hline 2. & Ruang Dahlia 2 & $\leq 0,5$ & 0,18 & MS \\
\hline 3. & Ruang Pear & $\leq 0,5$ & 0,89 & TMS \\
\hline
\end{tabular}

d. Pencahayaan di Dalam Ruang

Berdasarkan Tabel 5, dapat diketahui bahwa hasil pengukuran pencahayaan 
Dahlia 2 sebesar 26 lux, dan Ruang Pear sebesar 81 lux dengan kategori tidak

memenuhi syarat.

Tabel 5

Pencahayaan Ruang Rawat Inap di RS. Paru Surabaya Tahun 2016

\begin{tabular}{ccccc}
\hline No. & Ruangan & $\begin{array}{c}\text { Persyaratan } \\
\text { Pencahayaan (lux) }\end{array}$ & $\begin{array}{c}\text { Intensitas } \\
\text { Pencahayaan (lux) }\end{array}$ & Kriteria \\
\hline 1. & Ruang Dahlia 1 & $100-200$ & 62 & TMS \\
\hline 2. & Ruang Dahlia 2 & $100-200$ & 26 & TMS \\
\hline 3. & Ruang Pear & $100-200$ & 81 & TMS \\
\hline
\end{tabular}

\section{Proses Pembersihan dan Perawatan Ruang Rawat Inap}

Berdasarkan tabel 6 dapat diketahui bahwa hasil observasi proses pembersihan dan perawatan ruang rawat inap RS. Paru Surabaya Tahun 2016 pada masing-masing

Tabel 6

Hasil Observasi Proses Pembersihan dan Perawatan Ruang Rawat Inap RS. Paru Surabaya Tahun 2016

\begin{tabular}{|c|c|c|c|}
\hline No. & Ruangan & Variabel & Skor \\
\hline \multirow[t]{7}{*}{1.} & \multirow[t]{7}{*}{ Ruang Dahlia 1} & Pembersihan Lantai & 70 \\
\hline & & Pembersihan Dinding & 30 \\
\hline & & Pembersihan Langit-langit & 10 \\
\hline & & Pembersihan Pintu & 10 \\
\hline & & Pembersihan Ventilasi & 20 \\
\hline & & Total Nilai & $70 \%$ \\
\hline & & Kriteria & TMS \\
\hline \multirow[t]{7}{*}{2.} & \multirow[t]{7}{*}{ Ruang Dahlia 2} & Pembersihan Lantai & 70 \\
\hline & & Pembersihan Dinding & 30 \\
\hline & & Pembersihan Langit-langit & 10 \\
\hline & & Pembersihan Pintu & 10 \\
\hline & & Pembersihan Ventilasi & 20 \\
\hline & & Total Nilai & $70 \%$ \\
\hline & & Kriteria & TMS \\
\hline \multirow[t]{7}{*}{3.} & \multirow[t]{7}{*}{ Ruang Pear } & Pembersihan Lantai & 70 \\
\hline & & Pembersihan Dinding & 30 \\
\hline & & Pembersihan Langit-langit & 10 \\
\hline & & Pembersihan Pintu & 10 \\
\hline & & Pembersihan Ventilasi & 20 \\
\hline & & Total Nilai & $70 \%$ \\
\hline & & Kriteria & TMS \\
\hline
\end{tabular}

\section{Konstruksi Bangunan Ruang Rawat Inap}

Berdasarkan tabel 7, dapat diketahui bahwa hasil observasi konstruksi bangunan ruang rawat inap di RS. Paru Surabaya Tahun 2016 pada masing-masing ruang yaitu Ruang Dahlia 1, Ruang Dahlia 2, dan Ruang Pear tidak memenuhi syarat dengan prosentase yaitu sebesar $70 \%$. 


\begin{tabular}{|c|c|c|c|c|}
\hline No. & Ruangan & Variabel & Skor & Kriteria \\
\hline \multirow[t]{7}{*}{2.} & \multirow[t]{7}{*}{ Ruang Dahlia 2} & Lantai & 180 & MS \\
\hline & & Dinding & 80 & MS \\
\hline & & Ventilasi & 90 & MS \\
\hline & & Pintu & 70 & TMS \\
\hline & & Langit-langit & 0 & TMS \\
\hline & & Lain-lain & 200 & MS \\
\hline & & Total Nilai & $78 \%$ & MS \\
\hline \multirow[t]{7}{*}{3.} & \multirow[t]{7}{*}{ Ruang Pear } & Lantai & 180 & MS \\
\hline & & Dinding & 75 & MS \\
\hline & & Ventilasi & 90 & MS \\
\hline & & Pintu & 75 & MS \\
\hline & & Langit-langit & 0 & TMS \\
\hline & & Lain-lain & 200 & MS \\
\hline & & Total Nilai & $78 \%$ & MS \\
\hline
\end{tabular}

\section{Jumlah Pasien}

Jumlah pasien rawat inap dalam 3 tahun terjadi penurunan dari 1.884 orang Tahun 2012 menjadi 1.749 orang Tahun 2013 dan 1.704 orang Tahun 2014. Sejalan dengan penurunan jumlah pasien, frekuensi pemakaian tempat tidur dalam satu periode tertentu (Bed Occupancy Rate, BOR) berfluktuasi dari $46,48 \%$ Tahun 2012 menjadi 51,59\% Tahun 2013 dan 39,66\% Tahun 2014. Luas ruangan rawat inap seluas $65 \mathrm{~m}^{2}$ masing-masing ruangan berisi 6 bed dimana kebutuhan luas lantai tempat tidur per pasien seluas $7,5 \mathrm{~m}^{2}$. Rasio jumlah pasien terhadap luas lantai ruangan memenuhi syarat kesehatan.

\section{PEMBAHASAN}

Indeks Angka Kuman Udara Ruang Rawat Inap

Faktor risiko yang dapat berpengaruh terhadap jumlah angka kuman udara ruang yang tidak memenuhi syarat yaitu suhu udara ruang yang tidak memenuhi syarat, kelembaban udara ruang yang tidak memenuhi syarat, pencahayaan dalam ruang yang tidak memenuhi syarat, dan proses pembersihan dan perawatan ruang yang tidak memenuhi syarat. Hal ini sebagai faktor yang mempengaruhi banyaknya jumlah angka kuman di udara ruangan. Suhu udara yang tinggi akan menyebabkan udara makin renggang sehingga konsentrasi pencemar menjadi makin tinggi. Selain itu, kelembaban udara yang tinggi juga dapat meningkatkan pertumbuhan mikroorganisme Proses pembersihan dan perawatan ruang yang belum sempurna, seperti kegiatan pembersihan pada lantai yang hanya dilakukan satu kali sehari, dan tidak dilakukan pembersihan dengan desinfeksi setelah pasien keluar.

Tidak adanya pembatasan jumlah penunggu pasien dan kurang ketatnya jam kunjung pasien sehingga sering orang keluar masuk ruangan memungkinkan mereka membawa kuman dari luar. Selain itu, kondisi ruangan yang cenderung selalu terbuka dimana pintu jendela dan ventilasi yang sering dibiarkan terbuka juga berpotensi pada tingginya angka kuman.

Kualitas Fisik Udara Ruang Rawat Inap

1. Suhu Udara di Dalam Ruang

Hasil pengukuran suhu udara yang dilakukan diruang rawat inap RS. Paru Surabaya Tahun 2016 tidak memenuhi syarat. Hal ini dikarenakan ventilasi yang digunakan yakni ventilasi gabungan antara ventilasi alami dan ventilasi mekanis. Ventilasi mekanis yang digunakan pada masing-masing ruangan yakni Air Conditioner (AC), dan exhauster. Pada masing-masing ruangan tidak terdapat fan atau kipas angin. Air Conditioner (AC) yang terdapat pada masing-masing ruangan tidak berfungsi dengan baik, mengingat pasien yang dirawat adalah pasien penderita penyakit TBC. Sehingga, penggunaan Air Conditioner (AC) tidak diperbolehkan.

2. Kelembaban Udara di Dalam Ruang Hasil pengukuran kelembaban udara yang dilakukan di ruang rawat inap RS. Paru Surabaya Tahun 2016 tidak memenuhi syarat. Hal ini dikarenakan pintu ruangan yang selalu terbuka sehingga kelembaban bisa bertambah 
karena udara dari luar ruangan. Selain itu, suhu udara ruang yang tinggi juga mempengaruhi tingginya kelembaban udara karena berpengaruh pada penguapan kadar air dari kulit manusia sehingga akan menambah kadar uap air di udara.

3. Kecepatan Aliran Udara di Dalam Ruang

Hasil pengukuran kelembaban udara yang dilakukan di ruang rawat inap RS. Paru Surabaya pada ruang Dahlia 1 dan ruang Dahlia 2 tidak memenuhi syarat sedangkan pada ruang Pear tidak memenuhi syarat. Kecepatan aliran udara yang belum memenuhi syarat dapat dipengaruhi oleh posis ruang Dahlia dan ruang Pear yang yang menghadap ke arah Timur sementara arah angin adalah menuju ke arah Utara bisa juga mempengaruhi suhu udara ruang. Selain itu, ada atau tidak adanya hambatan yang berada ditengah ruangan. Misalnya, semakin besar furniture yang berdiri di antara ventilasi, maka semakin rendah kecepatan aliran udara tersebut.

4. Pencahayaan di Dalam Ruang Hasil pengukuran pencahayan udara yang dilakukan di ruang rawat inap RS. Paru Surabaya Tahun 2016 tidak memenuhi syarat. Hal ini dikarenakan ruangan yang terletak di belakang gedung utama. Sehingga pencahayaan alami tidak bisa masuk ke dalam ruang rawat inap. Serta kurangnya pencahayaan buatan yang ada di dalam ruangan.

Proses Pembersihan dan Perawatan Ruang Rawat Inap

Hasil observasi yang dilakukan pada petugas pembersihan dan perawatan ruang rawat inap RS. Paru Surabaya diketahui bahwa untuk satu area ruang rawat inap belakang ditangani oleh 2 petugas kebersihan (Cleaning Service) yang terbagi dalam 2 shif kerja yakni pagi dan malam. Pembersihan pada seluruh ruangan rawat inap dilakukan 1 kali dalam satu hari, pada pagi hari dilakukan pada pukul 07.30 WIB sedangkan pada sore hari dilakukan pada pukul 15.00 WIB.

Konstruksi Bangunan Ruang Rawat Inap

Hasil observasi yang telah dilakukan pada 3 ruang rawat inap yaitu Ruang Dahlia 1, Ruang Dahlia 2, dan Ruang Pear di RS. Paru Surabaya mengenai konstruksi bangunan ruang pada ruang rawat inap yang meliputi lantai, dinding, ventilasi, pintu, langit-langit, dan lain-lain memenuhi syarat.

\section{KESIMPULAN}

Berdasarkan hasil penelitian, maka dapat diambil kesimpulan bahwa indeks angka kuman udara ruang rawat inap RS. Paru Surabaya Tahun 2016 sangat tinggi sehingga tidak memenuhi syarat.

\section{SARAN}

1. Sebaiknya pembersihan ruangan dilakukan sesuai dengan prosedur pembersihan ruang perawatan, agar tercipta ruangan yang bersih, sehat, dan jumlah angka kuman udara dalam ruangan sesuai dengan jumlah yang dipersyaratkan.

2. Sebaiknya dilakukan perbaikan konstruksi ruangan yang belum memenuhi syarat, seperti jendela agar dapat buka-tutup, pintu agar dibuat dari bahan yang kuat dan dapat mencegah masuknya serangga dan binatang pengganggu.

3. Perlu dilakukan penelitian lebih lanjut apakah pembatasan jumlah pengunjung dan pemberlakuan jam kunjung secara ketat berpengaruh terhadap upaya penurunan angka kuman udara ruang disamping perbaikan kondisi fisik (suhu, kelembaban, pencahayaan, dan kecepatan aliran udara).

\section{DAFTAR PUSTAKA}

Darmadi, 2008. Infeksi Nosokomial Problematika dan Pengendaliannya. Jakarta,Salemba Medika:337.

Keputusan Menteri Kesehatan RI Nomor 1204/Menkes/SK/X/2004, Tentang Persyaratan Kesehatan Lingkungan Rumah Sakit.

Notoatmodjo, Soekidjo, 2012. Metodologi Penelitian Kesehatan. Jakarta, Rineka Cipta:115.

Pudjiastuti, Lily, dkk, 1998. Kualitas Udara Dalam Ruang. Jakarta, Departemen Pendidikan dan Kebudayaan:58.

Pratiwi, Kiki Ayu, dkk, 2013. Kualitas Mikrobiologi Udara di Ruang Rawat Inap Penyakit Menular di Rumah Sakit Paru Surabaya Tahun 2012. Gema Kesehatan Lingkungan (Vol.X No.1):1-4.

Waluyo, Lud, 2009. Mikrobiologi Lingkungan. Malang, UMM Press:337. 